\title{
Pertumbuhan dan Kadar Alkaloid Tanaman Leunca (Solanum americanum Miller) pada Beberapa Dosis Nitrogen
}

\author{
Growh and Alkaloids Levels of Leunca (Solanum americanum Miller) of Different Nitrogen \\ Application
}

Marchella Putriantari ${ }^{1}$ dan Edi Santosa ${ }^{1^{*}}$

Diterima 12 Agustus 2014/Disetujui 5 November 2014

\begin{abstract}
Leunca fruit is indigenous vegetable and widely used as vegetables mainly in West Java. In order to improve productivity and quality, several levels of nitrogen was used. The objective of the experiment was to determine the effect of nitrogen level on growth and productivity, and on the alkaloid levels. The experiment was conducted at Leuwikopo Experimental Station IPB in December 2013 - April 2014. Experiment was arranged in a Randomized Complete Block Design with single factor and four replications. Nitrogen fertilizer consisted of four levels, i.e., $0 \mathrm{~kg} \mathrm{~N} \mathrm{ha-1,60} \mathrm{kg} \mathrm{N}$ $\mathrm{ha}^{-1}, 120 \mathrm{~kg} \mathrm{~N} \mathrm{ha-1}$, and $180 \mathrm{~kg} \mathrm{~N} \mathrm{ha}$. The results showed that growth and productivity were affected by nitrogen application. The highest productivity of Leunca was obtained by nitrogen fertilizer at rate of $180 \mathrm{~N} \mathrm{ha}^{-1}$, and the highest alkaloid content was produced by plant treated with $60 \mathrm{~kg} \mathrm{~N} \mathrm{ha}{ }^{-1}$. The highest productivity of fruits was $18445 \mathrm{~kg} \mathrm{ha}^{-1}$.
\end{abstract}

Key words: alkaloid, indigenous vegetable, productivity, Solanum nigrum, nitrogen dosage

\begin{abstract}
ABSTRAK
Buah leunca merupakan sayuran indigenous terutama bagi masyarakat Jawa Barat. Dalam rangka meningkatkan produktivitas dan kualitas buah leunca, perlu dilakukan kajian budidaya khususnya pemupukan. Penelitian ini bertujuan menentukan dosis pupuk nitrogen terbaik untuk meningkatkan pertumbuhan dan produktivitas tanaman leunca, serta mengkaji pengaruh pupuk nitrogen terhadap kadar alkaloid tanaman leunca. Percobaan ini dilaksanakan di Kebun Percobaan Leuwikopo IPB pada bulan Desember 2013 - April 2014. Percobaan ini menggunakan Rancangan Kelompok Lengkap Teracak satu faktor dengan empat ulangan. Faktor dosis pupuk nitrogen terdiri atas empat taraf, yaitu tanpa pupuk $\mathrm{N}, 60 \mathrm{~kg} \mathrm{~N}^{-1}, 120 \mathrm{~kg} \mathrm{~N}^{-1}$, dan $180 \mathrm{~kg} \mathrm{~N} \mathrm{ha}^{-1}$. Hasil penelitian menunjukkan bahwa pertumbuhan dan produktivitas tanaman terbaik dihasilkan oleh perlakuan dosis pupuk nitrogen $180 \mathrm{~kg} \mathrm{~N} \mathrm{ha}^{-1}$. Kadar alkaloid tertinggi dihasilkan tanaman dari perlakuan dosis pupuk nitrogen $60 \mathrm{~kg} \mathrm{~N} \mathrm{ha}^{-1}$. Produktivitas buah leunca mencapai $18445 \mathrm{~kg} \mathrm{ha}^{-1}$.
\end{abstract}

Kata kunci: alkaloid, produkvitas, sayuran indigenous, Solanum nigrum, dosis nitrogen

\section{PENDAHULUAN}

Leunca (Solanum americanum Miller sinonim Solanum nigrum L.) adalah salah satu sayuran indigenous yang berasal dari Amerika Selatan (Siemonsma dan Jensen, 1994). Di Indonesia, leunca menyebar di Pulau Jawa dan Sumatera yang tersebar di lahan kering, baik di kebun atau di pekarangan rumah (Pratiwi, 2011). Bagian yang dikonsumsi adalah buah dan daun. Setiap 100 gram buah leunca segar mengandung $90 \mathrm{~g}$ air, $1.9 \mathrm{~g}$ protein, $0.1 \mathrm{~g}$ lemak, $7.4 \mathrm{~g}$ karbohidrat, $274 \mathrm{mg} \mathrm{Ca}, 4.0 \mathrm{~g} \mathrm{Fe}$, 0.5 g karoten, $0.1 \mathrm{mg}$ vitamin B1, dan $17 \mathrm{mg}$ vitamin C (Siemonsma dan Jensen, 1994). Oleh masyarakat, leunca diambil daun muda dan buahnya untuk dimanfaatkan sebagai sayuran yang dapat dimasak sebagai rebusan dan tumisan. Berdasarkan Penelitian Pratiwi (2011), $56.4 \%$ dari 90 responden menyatakan suka

${ }^{1}$ Departemen Agronomi dan Hortikultura, Fakultas Pertanian, Institut Pertanian Bogor

(Bogor Agricultural University), Jl. Meranti, Kampus IPB Darmaga, Bogor 16680, Indonesia

Telp.\&Faks. 62-251-8629353. *E-mail korespondensi: editoday@yahoo.com 
mengkonsumsi leunca. Namun demikian, sebagian besar buah leunca dipanen dari areal yang kurang pemeliharaan.

Selain dikonsumsi sebagai sayur, leunca dimanfatkan sebagai obat tradisional. Di Jawa Barat, leunca digunakan sebagai aprodisiak (Siemonsma dan Jensen, 1994), yakni zat yang merangsang daya seksual. Dalam literatur obat India kuno, buah S. nigrum memberikan efek menguntungkan pada peradangan, TBC, dan diuretik (Chopra et al.,1956 dalam Ravi et al., 2009). Ghani (2003) dalam Karmakar et al. (2010) menyatakan bahwa buah S. nigrum dapat digunakan untuk mengobati demam, diare, penyakit mata, penyakit jantung, edema anasarka (bengkak seluruh tubuh), penyakit anjing gila, pembesaran hati kronis, blood-spitting (batuk berdarah), ambeyen dan disentri. Penelitian Gogoi dan Islam (2012) menunjukkan buah S. nigrum memiliki kandungan metabolit sekunder yaitu alkaloid, saponin, tannin, dan flavonoid. Selain itu, terdapat gula pereduksi, glikosida, gum, dan steroid pada buah S. nigrum dari hasil skrining fitokimia (Karmakar et al., 2010). Metabolit-metabolit sekunder tersebutlah yang diduga berkhasiat sebagai obat. Jenis alkaloid pada S. nigrum yaitu solamargin, solasonin, dan solanin (Jain et al., 2011). Alkaloid yang terkandung pada daun yaitu solasonin dan solamargin, sedangkan pada buah terdapat solanin, solamargin, solasonin, $\alpha$ dan $\beta$ solanigrin, dan solasodin, serta solanin pada biji tanaman S. nigrum (Karmakar et al., 2010).

Potensi pengembangan yang besar tersebut, perlu didukung teknik budidaya yang baik khususnya pemupukan. Pupuk N dipilih sebagai perlakuan karena biasanya nitrogen memberikan pengaruh yang nyata dan cepat terhadap pertumbuhan vegetatif dan reproduktif tanaman. Selain itu, status $\mathrm{N}$ tanaman mempengaruhi kandungan alkaloid (Sirait, 2007). Di sisi lain, pemberian $N$ berlebihan dapat menyebabkan konsentrasi nitrat yang dapat menyebabkan sindrom blue baby. Karena itu, penentuan dosis $\mathrm{N}$ yang tepat sangat penting.

Tujuan penelitian adalah menentukan dosis pupuk $\mathrm{N}$ terbaik yang dapat meningkatkan pertumbuhan dan produktivitas tanaman leunca. Selain itu, mampu mengkaji pengaruh pupuk $\mathrm{N}$ terhadap kadar alkaloid tanaman leunca.

\section{METODE PENELITIAN}

\section{Tempat dan Waktu}

Penelitian dilaksanakan di Kebun Percobaan Leuwikopo, Departemen Agronomi dan Hortikultura, Fakultas Pertanian, IPB pada bulan Desember 2013 sampai April 2014. Analisis biomassa tanaman dilakukan di Laboratorium Pasca Panen, Departemen Agronomi dan Hortikultura, Fakultas Pertanian IPB, sedangkan analisis alkaloid dilakukan di Laboratorium Kimia Analitik, Departemen Ilmu Kimia, Fakultas Matematika dan Ilmu Pengetahuan Alam, IPB.

\section{Bahan dan Alat}

Bahan yang digunakan adalah benih tanaman leunca asal lokal Bogor, pupuk Urea, pupuk $\mathrm{KCl}$, pupuk SP-36, pupuk kandang kambing, dolomit, dan tray semai. Bahan untuk analisis alkaloid adalah buah leunca yang masih muda (berwarna hijau), heksana, metanol, asam sitrat $1 \mathrm{M}$, etil asetat, dan amonium hidroksida $6 \mathrm{M}$. Alat yang digunakan adalah oven, kamera digital, timbangan analitik, timbangan, meteran, rotary evaporator, corong pisah, kertas saring, $\mathrm{pH}$ meter, corong gelas, gelas piala, pengaduk gelas, dan sudip.

\section{Pelaksanaan}

Penelitian menggunakan metode Rancangan Kelompok Lengkap Teracak (RKLT) dengan satu faktor yaitu dosis nitrogen $(\mathrm{N})$. Dosis nitrogen terdiri atas empat taraf, yaitu tanpa N, $60 \mathrm{~kg} \mathrm{~N} \mathrm{ha}^{-1}, 120 \mathrm{~kg} \mathrm{~N}^{-1}$, dan 180 $\mathrm{kg} \mathrm{N} \mathrm{ha}{ }^{-1}$. Masing-masing perlakuan diulang sebanyak empat kali, sehingga terbentuk enam belas satuan percobaan. Pada setiap satuan percobaan diambil sepuluh tanaman contoh.

Persemaian benih leunca dilakukan selama 5 minggu. Media tanam di persemaian adalah campuran tanah dan pupuk kandang dengan perbandingan 1:1. Pada setiap satuan percobaan, penanaman dilakukan pada 3 bedengan. Ukuran bedengan adalah $7 \mathrm{~m}$ x $1 \mathrm{~m}$ dengan jarak antar bedengan adalah $50 \mathrm{~cm}$. Jarak tanam yang digunakan adalah $50 \mathrm{~cm} \mathrm{x}$ $70 \mathrm{~cm}$ (populasi $17760 \mathrm{ha}^{-1}$ ), yakni 2 baris setiap bedengan sehingga terdapat 20 tanaman dalam satu bedeng. Dolomit diberikan dua minggu sebelum tanam dengan dosis 1 ton ha ${ }^{-1}$ dengan cara disebar merata. Pupuk kandang 
kambing diberikan satu minggu sebelum tanam di sisi lubang tanam dengan dosis 10 ton $\mathrm{ha}^{-1}$ atau $0.59 \mathrm{~kg}$ lubang $^{-1}$. Analisis hara tanah secara lengkap dilakukan setelah dilakukan pengolahan tanah dan pemberian dolomit, yaitu pada 2 minggu setelah pemberian dolomit (setelah hujan deras).

Sebanyak 10 tanaman contoh diamati setiap minggu, yang dipilih secara acak. Pada satu minggu setelah tanam (MST), seluruh pupuk $\mathrm{P}$ dan $\mathrm{K}$ diberikan dengan dosis masingmasing yaitu $120 \mathrm{~kg} \mathrm{ha}^{-1}$ dengan cara ditabur di sekitar tanaman. Perlakuan pupuk $\mathrm{N}$ diberikan 2 kali yaitu $1 / 3$ dosis diberikan pada 1 MST dan sisanya $2 / 3$ dosis diberikan pada 6 MST dengan cara disebarkan sekitar tanaman lalu ditimbun tanah. Dosis N, P, dan K ditentukan dengan mengacu pada standar pemupukan tanaman tomat dengan dosis masing-masing yaitu $120 \mathrm{~kg} \mathrm{ha}^{-1}$ (Setiawati et al., 2007).

Pemeliharaan tanaman meliputi penyiraman dan pengendalian organisme pengganggu tanaman (OPT). Penyiraman dilakukan setiap hari bila tidak ada hujan. Penyiangan gulma dilakukan secara manual. Pengendalian OPT lain, seperti hama, dilakukan dengan membuang bagian tanaman yang terserang atau menjauhkan hama tersebut dari areal penanaman dan menggunakan pestisida yang sering digunakan pada tanaman tomat.

Pengamatan dilakukan setiap minggu hingga 16 MST. Kegiatan panen dimulai pada 7 MST yakni panen buah. Kriteria buah muda yang dipanen adalah buah yang hampir mencapai ukuran maksimum dan berwarna hijau. Panen dilakukan setiap satu minggu sekali.

\section{Pengamatan}

Peubah yang diamati adalah tinggi tanaman diukur dari permukaan tanah hingga pucuk tanaman tertinggi dan tinggi percabangan utama. Jumlah daun per tanaman. Daun yang dihitung adalah daun yang telah membuka sempurna dan panjang helai daun $\geq$ $1.5 \mathrm{~cm}$. Jumlah cabang per tanaman. Cabang yang dihitung memiliki panjang $\geq 2 \mathrm{~cm}$. Jumlah rangkaian bunga per tanaman contoh. Jumlah rangkaian buah per tanaman contoh dihitung saat panen.

Pengamatan terhadap produktivitas tanaman, meliputi: bobot basah, bobot kering, kadar air, bobot buah per 100 butir, persentase edible part, dan produktivitas tanaman. Sampel destruktif diambil pada 6 dan 12 MST dengan cara mencabut tanaman. Setelah dicabut, akar dibersihkan lalu masing-masing bagian tanaman dipisahkan, yaitu bagian akar, batang, daun, bunga, buah kecil berdiameter $\leq 3 \mathrm{~mm}$, buah sedang berdiameter 3.1-7 mm, dan buah besar berdiameter $>7 \mathrm{~mm}$. Masing-masing bagian ditimbang untuk memperoleh bobot basah. Jumlah sampel yang digunakan sebanyak 1 tanaman per satuan percobaan. Bobot kering diperoleh setelah dioven pada suhu $80{ }^{\circ} \mathrm{C}$ selama 3 x 24 jam. Peubah lain yakni kadar air, bobot buah per 100 butir, persentase edible part, dan produktivitas tanaman baik tanaman contoh maupun dari petakan.

Kandungan alkaloid diuji dengan metode ekstraksi pada buah leunca. Sebanyak $100 \mathrm{~g}$ buah leunca direndam heksana. Residunya disaring, kemudian direndam metanol. Filtrat metanol disaring dan dievaporasikan menggunakan rotary evaporator. Ekstrak pekat dihasilkan, kemudian diasamkan dengan asam sitrat $1 \mathrm{M}$ sampai $\mathrm{pH}$ 3. Ekstrak dipartisi etil asetat hingga menghasilkan fase etil asetat dan fase asam. Fase asam diambil dan dibasakan dengan ammonium hidroksida $\left(\mathrm{NH}_{4} \mathrm{OH}\right) 6 \mathrm{M}$ sampai pH 9. Ekstrak dipartisi lagi dengan etil asetat, sehingga terdapat fase basa dan fase etil asetat. Fase etil asetat dikeringkan, kemudian ditimbang residu alkaloidnya.

$$
=\frac{\begin{array}{c}
\text { Persentase kadar alkaloid } \\
\text { Bobot residu alkaloid }(\mathrm{g})
\end{array} \times 100 \%}{\text { Bobot sampel buah }(\mathrm{g})} \times
$$

\section{Analisis Data}

Pengolahan data dilakukan dengan UjiF. Apabila menunjukkan hasil yang berbeda nyata, dilakukan uji lanjut dengan Duncan Multiple Range Test (DMRT) pada taraf 5\%. Data yang menghasilkan nilai koefisien keragaman yang tinggi (> 25\%) ditransformasi dengan $\sqrt{(x+0.5)}$, x merupakan data asli.

\section{HASIL DAN PEMBAHASAN}

\section{Hasil}

Perlakuan dosis pupuk nitrogen berpengaruh nyata terhadap peubah-peubah yang diamati, selain tinggi percabangan utama dan 
kadar air (Tabel 1). Pupuk nitrogen memberikan respon positif meningkatkan pertumbuhan dan produktivitas tanaman leunca.

\section{Peubah Karakter Agronomi}

Tabel 2 memperlihatkan bahwa perlakuan dosis pupuk nitrogen berpengaruh nyata terhadap tinggi, jumlah daun, dan jumlah cabang tanaman leunca, tetapi tidak berpengaruh terhadap tinggi percabangan utama. Dosis pupuk nitrogen yang semakin tinggi menghasilkan pertumbuhan tanaman terbaik. Tinggi tanaman tertinggi serta jumlah daun dan cabang terbanyak dihasilkan oleh perlakuan dosis pupuk nitrogen $180 \mathrm{~kg} \mathrm{ha}^{-1}$. Namun demikian, peubah tinggi tanaman pada perlakuan dosis pupuk nitrogen 60,120 , dan $180 \mathrm{~kg} \mathrm{ha}^{-1}$ tidak berbeda nyata. Seperti halnya peubah jumlah daun pada perlakuan dosis pupuk nitrogen 120 dan $180 \mathrm{~kg} \mathrm{ha}^{-1}$ juga tidak berbeda nyata.

\section{Peubah yang Mempengaruhi Produktivitas Tanaman}

Jumlah rangkaian bunga, jumlah rangkaian buah, produktivitas, bobot 100 butir buah, dan persentase edible part tanaman leunca nyata dipengaruhi oleh perlakuan dosis pupuk nitrogen (Tabel 3). Perlakuan memberikan respon positif terhadap semua peubah tersebut, dengan menunjukkan hasil terbaik pada perlakuan dosis pupuk nitrogen $180 \mathrm{~kg}$ $\mathrm{ha}^{-1}$. Produktivitas buah tertinggi yaitu 18445 $\mathrm{kg} \mathrm{ha}^{-1}$ atau 18.455 ton $\mathrm{ha}^{-1}$, lebih tinggi dibandingkan produktivitas leunca di daerah Ciampea yaitu $1248 \mathrm{~kg} \mathrm{ha}^{-1}$ (Pratiwi, 2011). Persentase edible part berada pada kisaran 96.48-96.83\%, lebih tinggi dari edible part buah hijau pada Siemonsma dan Jansen (1994), yaitu 95\%.

\section{Peubah pada Pengamatan Sampel Destruktif}

Tabel 4 memperlihatkan bahwa bobot basah, bobot kering, jumlah akar, dan panjang akar nyata dipengaruhi oleh perlakuan dosis pupuk nitrogen. Namun demikian, kadar air tidak dipengaruhi oleh perlakuan dosis pupuk nitrogen. Bobot basah, bobot kering, dan jumlah akar tertinggi dihasilkan oleh perlakuan dosis pupuk nitrogen $180 \mathrm{~kg} \mathrm{ha}^{-1}$. Akan tetapi, panjang akar terpanjang dihasilkan oleh perlakuan dosis pupuk nitrogen $120 \mathrm{~kg} \mathrm{ha}^{-1}$. Pemupukan nitrogen mendorong akar tumbuh lebih dalam, karena adanya peningkatan luas daun sehingga lebih banyak hasil asimilasi untuk pertumbuhan akar (Gardner et al. 1991).

\section{Kadar Alkaloid Buah Leunca}

Tabel 5 memperlihatkan bahwa kadar alkaloid tertinggi dihasilkan oleh tanaman yang mendapatkan perlakuan dosis pupuk nitrogen $60 \mathrm{~kg} \mathrm{ha}{ }^{-1}$, yaitu sebesar $0.16 \%$. Kandungan alkaloid terendah hingga tertinggi secara berurutan dihasilkan oleh tanaman yang mendapatkan perlakuan dosis pupuk nitrogen $0,120,180$, dan $60 \mathrm{~kg} \mathrm{ha}^{-1}$.

Tabel 1. Rekapitulasi hasil analisis sidik ragam peubah-peubah yang diamati pada perlakuan dosis pupuk nitrogen

\begin{tabular}{|c|c|c|}
\hline Peubah & \multicolumn{2}{|c|}{ Dosis Pupuk N } \\
\hline Tinggi tanaman & \multicolumn{2}{|c|}{$* *$} \\
\hline Jumlah daun & \multicolumn{2}{|c|}{$* *$} \\
\hline $\begin{array}{l}\text { Tinggi percabangan } \\
\text { utama }\end{array}$ & \multicolumn{2}{|c|}{ th } \\
\hline Jumlah cabang & \multicolumn{2}{|c|}{$* *$} \\
\hline Jumlah rangkaian bunga & \multicolumn{2}{|c|}{$* *$} \\
\hline Jumlah rangkaian buah & \multicolumn{2}{|c|}{$* *$} \\
\hline Produktivitas & \multicolumn{2}{|c|}{$* *$} \\
\hline Bobot 100 butir buah & \multicolumn{2}{|c|}{$* *$} \\
\hline \multirow[t]{3}{*}{ Persentase edible part } & \multicolumn{2}{|c|}{$* *$} \\
\hline & 6 & 12 \\
\hline & MST & MST \\
\hline Bobot basah & $* *$ & $* *$ \\
\hline Bobot kering & $* *$ & $* *$ \\
\hline Kadar air & th & tn \\
\hline Jumlah akar & - & $* *$ \\
\hline Panjang akar & tn & $*$ \\
\hline
\end{tabular}


Tabel 2. Tinggi tanaman, jumlah daun, tinggi percabangan utama, dan jumlah cabang pada perlakuan dosis pupuk nitrogen

\begin{tabular}{|c|c|c|c|c|}
\hline $\begin{array}{l}\text { Dosis N } \\
\left(\mathrm{kg} \mathrm{ha}^{-1}\right)\end{array}$ & $\begin{array}{c}\text { Tinggi Tanaman } \\
(\mathrm{cm})^{\mathrm{a}}\end{array}$ & $\begin{array}{c}\text { Jumlah Daun } \\
\text { (helai) }^{\text {a }}\end{array}$ & $\begin{array}{c}\text { Tinggi Percabangan } \\
\text { Utama }(\mathrm{cm})^{\mathrm{a}}\end{array}$ & $\begin{array}{c}\text { Jumlah Cabang } \\
\text { (buah) }^{\mathrm{a}}\end{array}$ \\
\hline 0 & $92.83 b$ & $211.5 \mathrm{c}$ & $48.20 \mathrm{a}$ & $66.1 \mathrm{c}$ \\
\hline 60 & $110.72 \mathrm{a}$ & $313.0 \mathrm{~b}$ & $51.65 \mathrm{a}$ & $105.0 \mathrm{~b}$ \\
\hline 120 & $111.27 \mathrm{a}$ & $368.2 \mathrm{a}$ & $51.69 \mathrm{a}$ & $127.0 \mathrm{~b}$ \\
\hline 180 & $112.84 \mathrm{a}$ & $402.7 \mathrm{a}$ & $49.53 a$ & $159.7 \mathrm{a}$ \\
\hline KK (\%) & 4.19 & 9.9 & 3.95 & 16.7 \\
\hline
\end{tabular}

Tabel 3. Jumlah rangkaian bunga, jumlah rangkaian buah, produktivitas, bobot 100 butir buah, dan persentase edible part pada perlakuan dosis pupuk nitrogen

\begin{tabular}{rcccccc}
\hline $\begin{array}{c}\text { Dosis N } \\
\left(\mathrm{kg} \mathrm{ha}^{-1}\right)\end{array}$ & $\begin{array}{c}\text { Jumlah } \\
\text { Rangkaian }_{\text {Bunga }^{\mathrm{a}}}\end{array}$ & $\begin{array}{c}\text { Jumlah } \\
\text { Rangkaian }_{\text {Buah }^{\mathrm{a}}}\end{array}$ & $\begin{array}{c}\text { Produktivitas } \\
(\text { Tanaman } \\
\text { Contoh })(\mathrm{kg})^{\mathrm{a}}\end{array}$ & $\begin{array}{c}\text { Produktivitas } \\
(\text { Petak } \\
\text { Percobaan) } \\
(\mathrm{kg})^{\mathrm{a}}\end{array}$ & $\begin{array}{c}\text { Bobot 100 } \\
\text { Butir Buah } \\
(\mathrm{g})^{\mathrm{a}}\end{array}$ & $\begin{array}{c}\text { Persentase } \\
\text { Edible } \\
\text { Part }(\%)^{\mathrm{a}}\end{array}$ \\
\hline 0 & $239.1 \mathrm{~d}$ & $151.9 \mathrm{~d}$ & $5946.0 \mathrm{~d}$ & $5143.0 \mathrm{~d}$ & $62.69 \mathrm{~d}$ & $96.48 \mathrm{c}$ \\
60 & $378.7 \mathrm{c}$ & $246.8 \mathrm{c}$ & $11950.0 \mathrm{c}$ & $10788.0 \mathrm{c}$ & $66.56 \mathrm{c}$ & $96.59 \mathrm{~b}$ \\
120 & $496.2 \mathrm{~b}$ & $369.8 \mathrm{~b}$ & $16569.0 \mathrm{~b}$ & $13961.0 \mathrm{~b}$ & $69.16 \mathrm{~b}$ & $96.65 \mathrm{~b}$ \\
180 & $603.3 \mathrm{a}$ & $470.6 \mathrm{a}$ & $21073.0 \mathrm{a}$ & $18445.0 \mathrm{a}$ & $71.76 \mathrm{a}$ & $96.83 \mathrm{a}$ \\
\hline KK $(\%)$ & 14.0 & 15.6 & 14.1 & 14.3 & 2.34 & 0.06 \\
\hline Keterangan: KK: koefisien keragaman; angka-angka pada kolom yang sama dikuti huruf yang sama tidak berbeda nyata \\
berdasarkan uji DMRT pada taraf 5\%.
\end{tabular}

Tabel 4. Bobot basah, bobot kering, kadar air, dan panjang akar dari sampel destruktif 6 dan 12 MST pada perlakuan dosis pupuk nitrogen

\begin{tabular}{|c|c|c|c|c|c|}
\hline $\begin{array}{c}\text { Dosis N (kg } \\
\left.\mathrm{ha}^{-1}\right)\end{array}$ & $\begin{array}{c}\text { Bobot Basah } \\
(\mathrm{g})^{\mathrm{a}}\end{array}$ & $\begin{array}{c}\text { Bobot Kering } \\
(\mathrm{g})^{\mathrm{a}}\end{array}$ & $\begin{array}{c}\text { Kadar Air } \\
(\%)^{\mathrm{a}}\end{array}$ & $\begin{array}{c}\text { Jumlah } \\
\text { Akar }\end{array}$ & $\begin{array}{c}\text { Panjang } \\
\text { Akar }(\mathrm{cm})^{\mathrm{a}}\end{array}$ \\
\hline & \multicolumn{5}{|c|}{--------------------------- 6 MST . } \\
\hline 0 & $162.16 \mathrm{c}$ & $19.20 \mathrm{c}$ & $88.05 \mathrm{a}$ & - & $40.63 a$ \\
\hline 60 & $314.79 b$ & $39.66 b$ & $87.33 \mathrm{a}$ & - & $45.63 \mathrm{a}$ \\
\hline 120 & $396.62 b$ & $47.27 \mathrm{~b}$ & $88.05 \mathrm{a}$ & - & $59.43 \mathrm{a}$ \\
\hline 180 & $505.90 \mathrm{a}$ & $62.16 \mathrm{a}$ & $87.78 \mathrm{a}$ & - & $46.63 \mathrm{a}$ \\
\hline \multirow[t]{2}{*}{ KK $(\%)$} & 17.36 & 19.42 & 1.20 & - & $22.74 a$ \\
\hline & \multicolumn{5}{|c|}{------------------------------- 12 MST ------------------------------- } \\
\hline 0 & $149.24 \mathrm{c}$ & $24.99 \mathrm{c}$ & $83.64 \mathrm{a}$ & $14.8 \mathrm{~b}$ & $41.38 b$ \\
\hline 60 & $364.18 \mathrm{~b}$ & $60.98 \mathrm{c}$ & $83.40 \mathrm{a}$ & $32.0 \mathrm{a}$ & $66.33 a$ \\
\hline 120 & $466.14 \mathrm{ab}$ & $81.46 a b$ & $82.40 \mathrm{a}$ & $28.3 \mathrm{a}$ & $71.08 \mathrm{a}$ \\
\hline 180 & $555.52 \mathrm{a}$ & $106.65 \mathrm{a}$ & $81.05 \mathrm{a}$ & $41.5 \mathrm{a}$ & $69.30 \mathrm{a}$ \\
\hline KK (\%) & $14.08^{b}$ & $16.26^{\mathrm{b}}$ & 1.77 & $15.2^{\mathrm{b}}$ & 19.63 \\
\hline
\end{tabular}

Keterangan: KK: koefisien keragaman; MST: minggu setelah tanam; angka-angka pada kolom yang sama diikuti huruf yang sama tidak berbeda nyata berdasarkan uji DMRT pada taraf 5\%; berhasil transformsi $\sqrt{(x+0.5)}$. 
Tabel 5. Kadar alkaloid tanaman leunca pada perlakuan dosis pupuk nitrogen

\begin{tabular}{lc}
\hline $\begin{array}{r}\text { Dosis N (kg } \\
\left.\mathrm{ha}^{-1}\right)\end{array}$ & $\begin{array}{c}\text { Kadar Alkaloid 100 g } \\
\text { Buah }^{-1}(\%)\end{array}$ \\
\hline 0 & 0.03 \\
60 & 0.16 \\
120 & 0.05 \\
180 & 0.08 \\
\hline
\end{tabular}

\section{Pembahasan}

Perlakuan dosis pupuk nitrogen berpengaruh nyata terhadap pertumbuhan vegetatif dan produktivitas tanaman leunca. Nitrogen merupakan salah satu komponen utama klorofil (Munawar, 2011). Semakin banyak klorofil yang terbentuk, maka laju fotosintesis akan semakin tinggi. Perlakuan dosis pupuk nitrogen yang semakin tinggi menghasilkan pertumbuhan vegetatif tanaman leunca terbaik, yang ditunjukkan oleh peubah tinggi tanaman, jumlah daun, jumlah cabang, jumlah akar, dan panjang akar. Zulkarnain (2009) menyatakan dengan tercukupinya kebutuhan karbohidrat akan mempercepat laju pembelahan sel, pemanjangan sel, dan pembentukan jaringan, sehingga pertumbuhan batang, daun, dan akar juga akan berjalan cepat.

Pertumbuhan akar yang baik akan dapat memasok kebutuhan hara tanaman, sehingga pertumbuhan bagian atas tanaman akan menjadi baik pula. Pertumbuhan bagian atas tanaman, seperti tinggi tanaman, jumlah daun, dan jumlah cabang terbaik dihasilkan oleh tanaman yang mendapatkan perlakuan dosis pupuk nitrogen tertinggi yaitu $180 \mathrm{~kg} \mathrm{~N} \mathrm{ha}^{-1}$. Selain itu, perlakuan dosis pupuk nitrogen yang semakin tinggi juga menunjukkan pengaruh positif terhadap peubah jumlah rangkaian bunga, jumlah rangkaian buah, bobot basah, bobot kering, bobot 100 butir buah, persentase edible part, dan produktivitas buah. Tidak seluruh karbohidrat yang disintesis digunakan untuk pertumbuhan dan perkembangan organorgan vegetatif seperti batang, daun, dan akar, namun sebagian digunakan untuk perkembangan organ-organ reproduktif seperti bunga, buah, dan biji serta perkembangan organ-organ penyimpanan (Zulkarnain, 2009).

Pemberian pupuk nitrogen dengan dosis yang semakin tinggi menghasilkan tinggi tanaman tertinggi. Semakin tinggi tanaman, maka semakin banyak mata tunas yang di- hasilkan. Bertambahnya jumlah cabang diikut bertambahnya jumlah daun. Dengan demikian semakin banyak fotosintat yang dihasilkan. Penyebaran fotosintat ke seluruh bagian tanaman digunanakan untuk pertumbuhan dan perkembangan tanaman, tidak hanya untuk pertumbuhan vegetatif tetapi juga pertumbuhan organ reproduktif seperti bunga. Gardner et al. (1991) menyatakan bahwa adanya kelebihan hasil fotosintesis dapat mendorong proses diferensiasi, apabila termperaturnya menguntungkan dan tersedia enzim yang diperlukan Perlakuan dosis pupuk nitrogen berpengaruh meningkatkan tinggi tanaman, jumlah daun, jumlah cabang, jumlah rangkaian bunga, dan jumlah rangkaian buah, sehingga juga meningkatkan bobot basah dan bobot kering tanaman. Pupuk nitrogen sangat penting karena berpengaruh terhadap bobot kering tanaman. Biomassa tanaman rata-rata mengandung nitrogen sebesar 1-2\% dan mungkin lebih besar, yaitu 4-6\% (Gardner et al., 1991). Selain itu, perlakuan dosis pupuk nitrogen yang semakin tinggi juga meningkatkan produktivitas tanaman.

Kadar alkaloid yang dihasilkan masingmasing perlakuan dosis pupuk nitrogen berbeda-beda. Kadar alkaloid tertinggi dihasilkan oleh ekstrak buah dari tanaman yang mendapat perlakuan dosis pupuk nitrogen 60 $\mathrm{kg} / \mathrm{ha}$, yaitu sebesar $0.16 \%$. Pada penelitian Rolandani (2001), kadar alkaloid tertinggi dihasilkan oleh tanaman jahe dengan perlakuan tanpa pupuk nitrogen dan tidak ditumpangsarikan dengan kacang tanah. Sama halnya dengan penelitian Rolandani tersebut, kadar alkaloid tertinggi tidak dihasilkan oleh tanaman dengan perlakuan dosis pupuk nitrogen tertinggi. Hal ini diduga, tanaman cenderung menghasilkan metabolit sekunder pada kondisi tanah yang miskin hara. Namun demikian, pada perlakuan dosis pupuk nitrogen $0 \mathrm{~kg} \mathrm{ha}^{-1}$, kondisi hara nitrogen tanah yang sangat rendah tidak mampu mendukung pertumbuhan tanaman dengan baik, sehingga tidak mampu menjalankan metabolisme sekunder dengan baik pula. Nitrogen merupakan bahan penyusun alkaloid (Gardner et al., 1991). Ketersediaan nitrogen yang rendah menyebabkan rendahnya alkaloid yang dihasilkan.

Kadar alkaloid tidak meningkat sejalan dengan bertambahnya dosis pupuk nitrogen yang diberikan. Hal ini diduga, pertumbuhan tanaman yang subur akibat tercukupinya 
kebutuhan nitrogen membuat tanaman lebih tahan terhadap serangan OPT, sehingga tidak membutuhkan pelindung. Berbeda halnya, pada tanaman yang kurang subur, rentan terserang OPT, sehingga membutuhkan pelindung. Sunarminingsih (2002) menyatakan bahwa organisme yang tidak dapat menghindari serangan predator menghasilkan suatu senyawa yang digunakan untuk menghalau predator tersebut, tetapi tidak berfungsi untuk pertumbuhan. Pada jenis Solanaceae, alkaloidalkaloid digunakan untuk mempertahankan diri dari serangan serangga jenis kolorado (Sirait, 2007). Jika budidaya leunca ditujukan untuk mengambil metabolit sekundernya, dapat diterapkan perlakuan dosis pupuk nitrogen $60 \mathrm{~kg} \mathrm{ha}^{-1}$. Pada perlakuan tersebut, produktivitas buah lebih rendah, tetapi produktivitas alkaloidnya lebih tinggi.

Beberapa peubah yang diamati memiliki nilai koefisien keragaman (KK) yang tinggi sehingga data perlu ditransformasi. KK menunjukkan tingkat keragaman suatu perlakuan antar ulangan. Peubah-peubah yang memiliki nilai KK yang tinggi yaitu bobot basah, bobot kering, dan jumlah akar pada 12 MST. Nilai KK yang tinggi dipengaruhi oleh lingkungan percobaan. Kesuburan tanah yang berbedabeda pada setiap bedeng percobaan dapat mempengaruhi pertumbuhan tanaman, sehingga berpengaruh terhadap peubah-peubah yang diamati. Gardner et al. (1991) menyatakan bahwa tanah bervariasi secara morfologis, fisik, kimia, dan biologis.

\section{KESIMPULAN}

Pada penelitian ini, perlakuan pemupukan nitrogen meningkatkan pertumbuhan vegetatif (tinggi tanaman, jumlah daun, jumlah cabang, jumlah akar, dan panjang akar) dan produktivitas tanaman leunca. Pertumbuhan dan produktivitas terbaik dihasilkan oleh perlakuan dosis pupuk nitrogen $180 \mathrm{~kg} \mathrm{ha}^{-1}$. Perlakuan pemupukan nitrogen berpengaruh terhadap kandungan alkaloid pada buah leunca. Kandungan alkaloid tertinggi dihasilkan oleh perlakuan dosis pupuk nitrogen $60 \mathrm{~kg} \mathrm{ha}^{-1}$. Dengan demikian, dosis rekomendasi ditentukan berdasarkan tujuan dari kegiatan budidaya.

\section{SARAN}

Perlu dikaji lebih lanjut jenis alkaloid dan kadar dari setiap jenis alkaloid yang dihasilkan dari perlakuan dosis pupuk nitrogen yang berbeda.

\section{DAFTAR PUSTAKA}

Gardner, F.P, R.B. Pearce, R.L. Mitchell. 1991. Fisiologi Tanaman Budidaya. Susilo H, penerjemah. UI Pr. Terjemahan dari: Physiology of Crop Plants. Jakarta.

Gogoi, P., M. Islam. 2012. Phytochemical screening of Solanum nigrum $\mathrm{L}$ and $S$. myriacanthus Dunal from Districts of Upper Assam, India. IOSR. 2(3)-455459. http://www.iosrphr.org/papers/v2i3/ S023455459.pdf. [14 November 2013].

Jain, R., A. Sharma, S. Gupta, I.P. Sarethy, R. Gabrani. 2011. Solanum nigrum: current perspectives on therapeutic properties. AMR. 16(1): 78-85. http://www. altmedrev. com/publications/16/1/78.pdf. [25 Januari 2014].

Karmakar, U.K., U.K. Tarafder, S.K. Sadhu, N.N. Biswas, M.C. Shill. 2010. Biological investigation of dried fruit of Solanum nigrum Linn. S J. Pharm Sci. 3(1): 3845. http://www.banglajol.info/ index.php/ SJPS/article/view/6796/5186. [14 Nov 2013].

Munawar, A. 2011. Kesuburan Tanah dan Nutrisi Tanaman. IPB Pr. Bogor.

Pratiwi, U. 2011. Evaluasi beberapa karakter agronomi, nilai gizi dan persepsi masyarakat terhadap tanaman indigenous di Jawa Barat. Skripsi. Institut Pertanian Bogor. Bogor.

Ravi, V., T.S.M. Saleem, S.S. Patel, J. Raamamurthy, K. Gauthaman. 2009. Anti-inflammatorry effect of methanolic extract of Solanum nigrum Linn Berries. IJARNP. 2(2): 33-36. http:// www.ijarnp. org/index.php/ijarnp/article/view/56/57. [14 November 2013]. 
Rolandani, J. 2001. Pengaruh fiksasi nitrogen kacang tanah dan taraf nitrogen dalam pupuk terhadap kadar alkaloid dalam rimpang jahe. Skripsi. Institut Pertanian Bogor. Bogor.

Setiawati, W., R. Murtiningsih, G.A. Sopha, T. Handayani. 2007. Petunjuk Teknis Budidaya Tanaman Sayuran. Balitsa. Bandung.

Siemonsma, J.S., P.C.M Jansen. 1994. Solanum americanum Miller. Di dalam: Siemonsma, J.S., K. Piluek, editor. Plant Resources of South-East Asia. PROSEA. Voume 8. Vegetable. Prosea. hlm 252-255. Bogor.
Sirait, M. 2007. Penuntun Fitokimia dalam Farmasi. ITB Pr. Bandung.

Sunarminingsih, R. 2002. Metabolit Sekunder: Manfaat dan Perkembangannya dalam Dunia Farmasi. Pidato pengukuhan jabatan guru besar Fakultas Farmasi Universitas Gadjah Mada diucapkan di depan rapat terbuka Majelis Guru Besar Universitas Gadjah Mada pada tanggal 12 Oktober 2002 di Yogyakarta. http:// mgb.ugm.ac.id/media/download/ pidatopengukuhan.html?download $=276$ \&start $=190$. [16 November 2013].

Zulkarnain. 2010. Dasar-Dasar Hortikultura Rachmatika R, editor. Bumi Aksara. Jakarta. 